\section{I want a new drug}

IN July 1981, the San Francisco General Hospital saw its first case of Kaposi's sarcoma. Twelve years and thousands of deaths later, nobody would argue that the best and most informed care of AIDS patients comes from work at SF General.

Similarly, it would be hard to deny that the epidemic has had a profound effect on society outside the hospital. The impact of AIDS has been so great that nobody has escaped - in a city where even daytime radio programming has an explicitly homosexual cast, you cannot help becoming involved. Today, about 60 per cent of homosexual men in San Francisco are infected, probably the highest density of infection anywhere in the developed world. "It colours everything we do out here", says activist Martin Delaney, "the gay community, to a large extent, is about addressing AIDS. It has to be, because it's literally a war: your entire community is under siege."

Over the past decade, the traditional lines between researcher, physician, patient and activist have all but washed away, leaving a loose network of people of less-well-defined activity, but all concerned in fighting AIDS. Brook Byers, venture capitalist, lives in in a wellheeled, tree-lined district overlooking the Golden Gate. He kick-starts companies such as Genentech, long involved in AIDS research. Linda Sonntag, chief executive officer of another company, SyStemix, lives around the corner. SyStemix researcher Mike McCune (who lives in the same street as Sonntag) is developing a strain of SCID mouse with a transplanted human immune system, research that suggests radical therapies against AIDS. McCune is a member of the Immune Restoration Think-Tank, an independent study group organized by

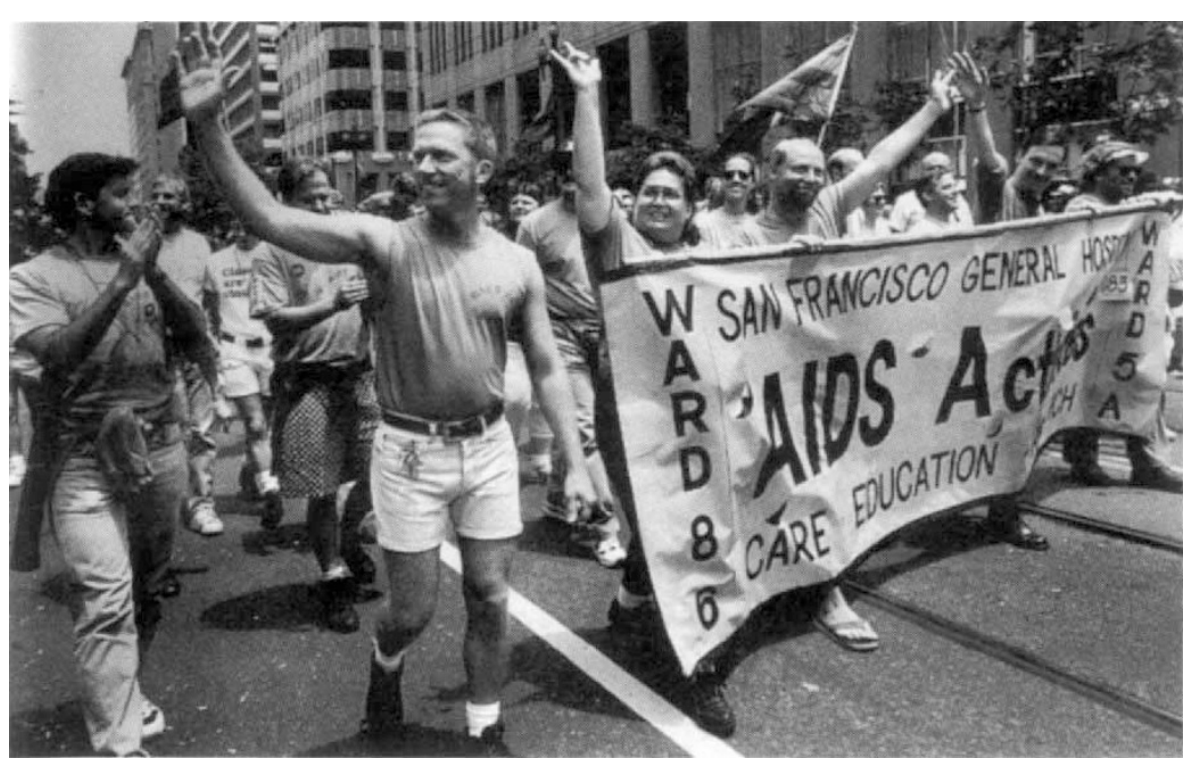

St General takes to the streets.
Delaney's pressure-group Project Inform (PI), one of the longest-established AIDS awareness groups. Project Inform has an office in the Castro on the other side of town, the epicentre of San Francisco gay life.

Delaney achieved some notoriety in the mid-1980s for the organization of alternative trials of the experimental

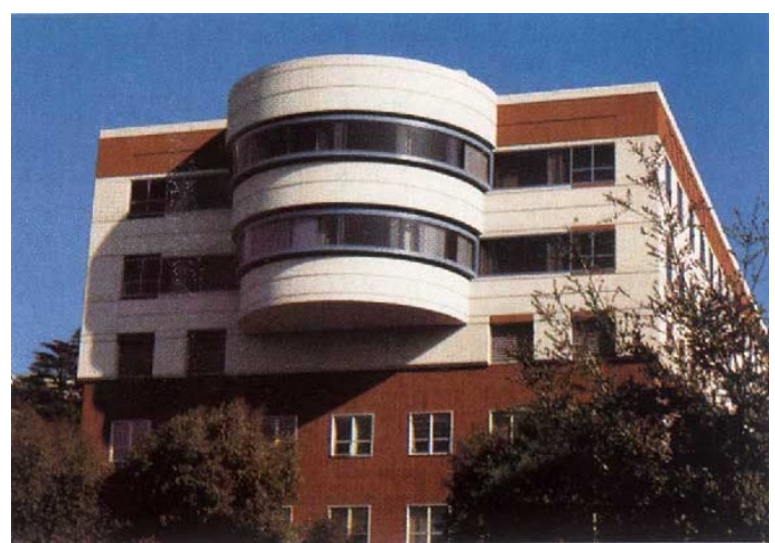

The new Gladstone Institute of Virology and Immunology has a particular focus on HIV and AIDS.

drug GLQ223, a substance extracted from Chinese herbal remedies and popularly known as Compound $\mathrm{Q}$, in an attempt to subvert the usual testing and approval procedure - which, to sick patients, seemed inordinately and perhaps lethally protracted. (GLQ223 is currently in Phase II efficacy trials at SF General.)

One of the doctors who participated in the alternative $\mathrm{Q}$ trial, and also a member of the think-tank, is general practitioner Larry Waites, who lives in a leafy street of terrifying gradient not far from the PI office. As one of five doctors in the 450 Sutter medical practice, he has New Drug".

$1700 \mathrm{HIV}$-positive patients on his books $\mathrm{He}$ and others have been able to work with drug companies, the Food and Drug Administration and the hospitals in a programme of community-based clinical trials. And back at SF General is Warner Greene, keen to roll up his sleeves as director of the brand new Gladstone Institute of Virology and Immunology at SF General and get on with some fundamental research, but mindful of the activist contribution to AIDS care.

All in all, AIDS has produced a society with a distinctive character found perhaps nowhere else on Earth. It is as much a feature of the city as the cablecars, the Golden Gate and the vertically challenging streets. In this context, it is perhaps interesting that the single most generous private donation to the AIDS programme at SF General came not from an endowment or foundation but from a local rock group called Huey Lewis and the News. In 1983, long before the $\mathrm{Q}$ controversy, the group had a hit song called "I Want A

When AIDS struck, it struck hard. In a single year, 1982, 21 per cent of the uninfected gay male population became infected, and for some reason not yet known, many of those infected early, died early. "Soon everyone, and I mean everyone, had a friend who was dying", says Delaney. "It seemed as if the entire city in the late eighties was in mass depression", remembers Waites. "It [AIDS] has already completely changed our lives", says Warner Greene: "there is almost a paranoia about the virus. I don't know if we can equate it to the bubonic plague of the Middle Ages, but certainly it is the most serious epidemic that we have faced in the last 100--200 years."

Ultimately, HIV's biggest mistake may have been that of all the places in the West to unleash its initial onslaught, it chose a city in California, where people are disinclined to accept that impossible tasks must always remain so. "The pioneer spirit is still very much alive in California", says Waites, "and people don't accept the status quo the way they would on the East Coast, where they would say 'Oh well, there people are going to die, let's just make them as comfortable as possible'. In the Immune Restoration Think-Tank, we don't accept the fact that people with less than $50 \mathrm{~T}$ cells [per ml] are automatically going to die. There must be something we can do to save these people, and by doing this, what we learn will help us to treat people with less damaged immune systems." 